\title{
Parents' Desire to Make Equal Inter Vivos Transfers
}

\author{
ELIN HALVORSEN \\ THOR O. THORESEN
}

CESIFO WORKING PAPER No. 2468

CATEGORY 1: PUBlic FinANCE

NOVEMBER 2008

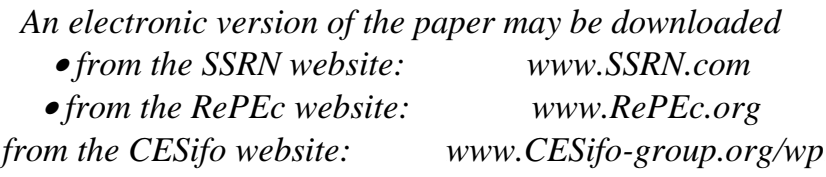




\title{
Parents’ Desire to Make Equal Inter Vivos Transfers
}

\begin{abstract}
This study argues that parents have a desire for dividing equally between their children, and that this motive applies to transfers of gifts inter vivos. We suggest that the equal division motive competes with traditional altruism: support to the child or the children with greatest needs. When parents are drawn between these two ambitions, the degree of income compensation should be stronger in one-child families and we expect the altruism motive to dominate the equal division desire at low levels of recipients' income. We find support for both these hypotheses, when analysing Norwegian data for inter vivos transfers behaviour. The data include information about stated attitudes towards transfers among the parents, which also support the equal division motive.
\end{abstract}

JEL Code: D64, D91, H21.

Keywords: inter vivos gifts, equal divisions, altruism, sibling comparisons.

Elin Halvorsen
Statistics Norway
Research Department
P.O. Box 8131 Dep.
0033 Oslo
Norway
elin.halvorsen@ssb.no

Elin Halvorsen

Research Department

0033 Oslo

elin.halvorsen@ssb.no 


\section{Introduction}

The altruism model (Barro, 1974; Becker, 1974; Becker and Tomes, 1979) suggests that parents compensate their children and divide transfers unequally between children whose needs are different. However, empirical analyses find weak support for the predictions of the altruism model, as parents often transfer equal amounts to their children. How should one interpret this finding? One would reasonably assume that most parents are essentially altruistic towards their children in the sense that they care about their children's welfare and consumption possibilities. However, it is also reasonable to assume that they would like to treat their children equally. If parents' have preferences for equal sharing, they will have to weigh their altruism against a desire for equal divisions.

The equal division question has received attention in the literature on intergenerational transfers; see for instance Menchik (1988), Wilhelm (1996), Stark (1998), Lundholm and Ohlsson (2000), and Bernheim and Severinov (2003). A number of papers discuss intergenerational linkages through inter vivos giving behaviour (as in the present paper) instead of addressing information on bequests, see Altonji et al. (1997) and Poterba (2001). The growing awareness of parents' transfer behaviour before death appears to have emerged because recent findings, for instance from the U.S., suggest a majority of parents divide their estates equally between children at death, while inter vivos gift behaviour to a larger extent results from parents' response to characteristics of children (Dunn and Phillips, 1997; McGarry, 1999). This has prompted theories focusing on heterogeneity between bequests and gifts in terms of observability (Arrondel and Masson, 2006); see Lundholm and Ohlsson (2000) and Bernheim and Severinov (2003).

Here, it is argued that parents have a desire to make equal divisions and that this also applies for transfers before death. To our knowledge, this is the first study to explicitly focus on parents' desire to divide inter vivos transfers equally. Parents are averse to inequality, we suggest, as for instance Behrman et al. (1982) have found. However, they are drawn between the ambitions to divide equally and support the child or the children with greatest needs.

In order to discuss this, we employ a dataset of (non-taxable) inter vivos transfers between generations in Norway. Of particular salience here is that the respondents were asked questions relating to both their children and parents. We can therefore study the relationship between the respondent and her parents (if they are still alive) or the respondent and all her (grown-up) children. We use information on respondents and their parents, discussing two implications of parents trading-off "pure altruism" and equal divisions: the degree of income compensation should be stronger in one-child families since equal division considerations would not apply in these families, and altruism would dominate the preferences for equal division when children have income substantially below mean or median income 
levels, generating a non-linear relationship between transfers and recipient income. Moreover, the respondents were also asked to state their transfer motives, such as what kind of division rule one should follow if one would like to help the children economically. These responses are also reported. The data also open up for addressing within families evidence: we use information about respondents' children, comparing siblings belonging to the same family, to determine what child characteristics (relative to the other children of the family) that determines unequal sharing.

An important argument for addressing inter vivos transfer behaviour in the present study is that the equal division rule is in fact part of public policies in Norway. The Norwegian law of transmission limits parents' possibilities to differentiate between the descendants through bequests, as only one third of the estate can be transferred according to bequeathers' preferences. Two thirds of the estate is reserved for equal sharing between children. The same regulations apply to gifts that are advancements of inheritance, since they are an integrated part of inheritance tax bases. Also, we expect that the progressive schedule of the Norwegian inheritance tax contributes to parents levelling out transfers to children. Thus, we assume that parents who face restrictive transmission rules and a progressive tax schedule and still want to transfer resources to their children in accordance with their preferences, will transfer resources in terms of (non-taxable) inter vivos gifts.

In our empirical analyses, we find that parents pass on more gifts to a child that have a more difficult situation compared to her/his siblings, which give support to parents being altruistic. However, we find that the recipient income derivative is significantly higher in one-child families than in multiple child families, and furthermore, the derivative in multiple child families is non-linear, with a larger degree of parental compensation among children whose income is lower than mean or median income. We take this as corroborative evidence for the hypothesis that parents are faced with a trade-off between being compensatory and dividing equally.

These results give support to the view that equal divisions are intentional, and should not be interpreted as a sign of indifference from the benefactors side. Whereas unintended transfers may strenghten the case for taxation of transfers, because taxes are less distortive with respect to donors' behaviour when transfers are not intentional, equal divisions should not be interpreted as promoting the case for intergenerational transfer taxes. In light of this, one may discuss to what extent equal divisions can be seen as a feature of altruism, as suggested by Stark (1998), but that is not an issue here.

The plan of the paper is as follows: in Section 2 we discuss a simple model of transfer behaviour for parents having preferences both for dividing equally and being altruistic. The institutional setting for the parents, such as Norwegian trans- 
mission laws and tax regulations, are discussed in Section 3. Section 4 describes the data, whereas results from the different approaches to derive information on altruism and equal divisions are presented in Section 5 and Section 6. First, in Section 5 we discuss which child characteristics that encourage transfers, given that are our basic reasoning is founded on altruism, also analysing within family evidence (grown children belonging to the same family) on characteristics promoting unequal divisions. Thereafter, in Section 6 we explore the parental struggle between altruism and equal divisions further by discussing two hypotheses: there is more altruism in one-child families and existence of a non-linear relationship between transfers and child income. Section 7 presents information on parents' self-reported motives for transfers to children, whereas Section 8 concludes the paper.

\section{Altruism with equal division considerations}

Equal divisions might be seen as resulting from precautionary savings under a life-cycle model; see Davies (1981) for accidental bequests. Taxation of accidental bequests does not have harmful effects on donor's behaviour. However, some studies, such as Stark (1998) and Bernheim and Severinov (2003), argue that equal divisions are intentional and can be interpreted as following from the behaviour of altruistic parents. The altruism model (Barro, 1974; Becker, 1974; Becker and Tomes, 1979) has been at the centre of empirical investigations of transfer motives, see Altonji et al. (1997) and Laitner and Ohlsson (2001). Another alternative is that parents are motivated by strategic considerations, supporting their children in exchange of attention and services (Bernheim et al., 1985; Cox, 1987).

Here we present a modified version of the altruism model that incorporates preferences for equal divisions. A similar model can be found in Lundholm and Ohlsson (2000). Altruistic parents derive positive utility from own consumption, $c_{p}$, and their children's consumption, where $c_{i}$ is the consumption of child $i$ and $n$ is the number of children, determined by own earnings, $e_{i}$, and transfers from parents, $b_{i}$. Most notably, we open up for parents disliking unequal sharing of gifts, represented by an inequality aversion supplement. Consumption of parents and children, respectively, can be seen as

$$
c_{p}=e_{p}-\sum_{i=1}^{n} b_{i}
$$

and

$$
c_{i}=e_{i}+b_{i}, \quad i=1, \ldots, n,
$$


where $e_{p}$ is parental earnings. Assuming log linear parental utility of own consumption and children's consumption, representing inequality by $b_{i} / \bar{b}$, where $\bar{b}=$ $\sum_{i} b_{i} / n$, and introducing two parameters, measuring the degree of altruism, $\alpha$, and aversion towards inequality, $\gamma$, we have

$$
U=\ln c_{p}+\alpha \sum_{i=1}^{n} \ln c_{i}-\gamma \sum_{i=1}^{n}\left|\ln \frac{b_{i}}{\bar{b}}\right|
$$

Focusing on a parent who makes transfers to the children, in interior solution, $b_{i}>0$, the optimisation problem can then be formalised as

$$
\begin{aligned}
\max _{b_{1}, \ldots, b_{n}} U= & \ln \left(e_{p}-\sum_{i=1}^{n} b_{i}\right) \\
& +\alpha \sum_{i=1}^{n} \ln \left(e_{i}+b_{i}\right)-\gamma \sum_{i=1}^{n}\left|\ln \frac{b_{i}}{\bar{b}}\right|,
\end{aligned}
$$

To illustrate the implications of this model, consider the first order conditions in the case of two children:

$$
\left(b_{2}-b_{1}\right)\left[1+\frac{\gamma}{\alpha} \frac{\left(e_{1}+b_{1}\right)\left(e_{2}+b_{2}\right)}{b_{1} b_{2}\left(b_{1}+b_{2}\right)}\right]=e_{1}-e_{2}
$$

If there is no equal division attitudes $(\gamma=0)$ then

$$
b_{2}-b_{1}=e_{1}-e_{2}
$$

This is the standard result of the altruism model. Parents treat their children symmetrically, and taking the $e_{i}$ 's as given, they balance their gifts and bequests in order to equalise children's consumption, net of transfers. We have that $\partial b_{i} / \partial e_{i}<0$, which states that a transfer to child $i$ is decreasing in the child's income. This derivative together with a second implication of altruism, that transfers increase with parent's income, $\partial b_{i} / \partial e_{p}>0$, have been at the core of empirical studies of altruism. In particular, analyses of the standard model of altruism often focus on the transfer-income derivative restriction, which states that these two derivatives should add to 1, see e.g., Cox and Rank (1992); Altonji et al. (1997) and Laitner and Ohlsson (2001). However, empirical analyses find weak support for the predictions of the altruism model, as parents often transfer equal amounts to their children. However, some differences between bequests and gifts have been reported: a majority of parents divide their estates equally between children at death, while inter vivos gift behaviour to a larger extent results from parents' response to characteristics of children (Dunn and Phillips, 1997; McGarry, 1999). Theoretical contributions to explain this can be found in Lundholm and Ohlsson 
(2000) and Bernheim and Severinov (2003). Lundholm and Ohlsson assume that the cost of unequal division is only associated with bequests since these are public information, and parents who are worried about their post mortem reputation will use gifts to treat children unequally, as gifts to a larger extent are private information. Bernheim and Severinov develop equal division norm equilibriums for bequests from altruism, when an element of parental affection is added, affecting well-being of children and observed through parental transfer behaviour. Within such an approach gifts may be transferred more unequally, "in secret".

In the present paper we argue that $\gamma>0$ and that such motives also apply for transfers before death. Therefore an important reason for not finding evidence that confirm altruism is that the equalisation is hampered by equal division desires or aversion to inequality. Parents aversion to inequality is in accordance with results from Behrman et al. (1982) and is also discussed by Wilhelm (1996); the latter study refers to unequal divisions of bequests as generating psychic costs. When $\gamma>0$, then

$$
\left[1+\frac{\gamma}{\alpha} \frac{\left(e_{1}+b_{1}\right)\left(e_{2}+b_{2}\right)}{b_{1} b_{2}\left(b_{1}+b_{2}\right)}\right]>1
$$

and

$$
b_{2}-b_{1}<e_{1}-e_{2},
$$

i.e. parents will compensate less than in the case where they did not have a negative utility of dividing unequally. The larger the equal division parameter $\gamma$ is, compared to the altruism parameter $\alpha$, the less they compensate income gaps between children. These results are easily generalised to the case with more than two children, and they also hold in a more general model.

With respect to the two conjectures discussed in this paper, that the degree of income compensation should be stronger in one-child families, since these families are not influenced by equal division motives, and that the pure altruism motive will dominate preferences for equal division when income differences between siblings are large, we address estimates of the recipient income derivative, $\partial b_{i} / \partial e_{i}$. In the first case, we compare estimates of $\partial b_{i} / \partial e_{i}$ in one-child families with estimates from larger families. In order to discuss the second conjecture, we discuss non-linearity of $\partial b_{i} / \partial e_{i}$, arguing that the we will find more "pure altruism" at low levels of income, where we find children with incomes substantially below the income levels of their siblings. 


\section{Norwegian gift and bequest laws suggest equal divisions}

As already noted, if transfers to children signal parental affection, and as gifts are often less observable than bequests, there are reasons to address information on inter vivos giving behaviour when discussing altruistic motives. Here we also note that in the Norwegian case, public regulations limit the scope for altruistic behaviour. There are at least two sets of laws that impact on transfer behaviour of Norwegian parents: the transmission law and the inheritance tax law. The law of transmission between generations regulates the opportunity for compensatory activities. It states that children (biological or adopted) are guaranteed two thirds of the estate, for values up till NOK 1 million (approximately US\$155,000) ${ }^{1}$ per person. This appears to be similar to what Arrondel and Laferrère (2001) report as the case in France, and which they characterise as "directive altruism", that is a legal system that encourages transfers to close relatives. Transmission laws that are directive with respect to transfer to children exist in a number of other European countries (Pestieau, 2003).

More important with respect to empirical analyses of altruism in the Norwegian system, each child is guaranteed an equal share of this mandatory transfer to children. If a parent leaves NOK 750,000, her two children will receive a mandatory share of 250,000 each, while the bequeather can freely target the remaining 250,000 according to her objectives in a will: to one of them, to charity, etc. ${ }^{2}$ Thus, Norwegian parents are restricted by the law of transmission, making Norwegian bequest data less useful for deriving information about transfer motives, as testing the conjectures of the altruism model, since parents may be constrained from carrying out their true objectives.

We assume that parents under such circumstances will carry out their intentional transfer arrangements through inter vivos gifts. The law states unequivocally that an equal sharing principle does not exist with respect to inter vivos transfers that are not advanced bequests. Such inter vivos gifts are also tax exempt. Inter vivos gifts that are considered as advancement of inheritance are both part of the tax base and limited by transmission laws. At the time of setting up the empirical approach followed in this study there was no set amount that specified when a gift was to be reported to tax authorities, and we chose to consider transfers below NOK 40,000 (approximately US\$ 6,200) per year as non-taxable inter

\footnotetext{
${ }^{1}$ We use the average exchange rate betwen Norwegian kroner (NOK) and US dollars (US\$) for 2005, $1 \mathrm{US} \$=6.45 \mathrm{NOK}$, here and throughout the paper.

${ }^{2}$ Only about 25 percent of donors transfer their assets according to a will (Ministry of Finance, 2000), which indicates that many parents follow the equal division rule also for the "free" part of the bequest.
} 
vivos gifts. However, from 2008 this is formalised, the tax authorities stating that a gift of half of the so-called basic amount from the National Insurance Scheme is tax exempt. Fortunately, this is very close to our choice of NOK 40,000.

The inheritance tax is progressive and based on aggregated values of taxable gifts and bequests, see Appendix A where the tax scheme is enumerated. There are reasons to assume that a progressive inheritance tax also acts as an incentive to divide bequests equally. In light of these regulations, namely the law of transmission and the tax law, we believe information from inter vivos transfer behaviour rather than information on bequests and taxable inter vivos transfers, is relevant to our discussion of altruism in intergenerational transfers in Norway. These transfers are as such untainted by provisions set out in the law of transmission and the inheritance tax law.

This paper discusses implications of the struggle between "pure altruism" and equal divisions, not discussing where the equal division motive comes from; see Bernheim and Severinov (2003) for equilibrium results of equal divisions. However, it is worth noting that equal division, at least to some extent, is part of Norwegian public policy. Parents might also adhere to the equal division rule with respect to the non-mandatory share as well; the equal sharing rule constituting a transfer norm introduced by public regulations?

\section{Descriptions of data}

In order to discuss the degree of altruism in families one should ideally have data that cover families' transfer behaviour over a long time period under shifting circumstances, life-cycle data most preferably. However, here we follow the identification strategy of many other studies by addressing information from cross-section data (Laferrère and Wolff, 2006). We exploit very detailed data from a survey conducted by Norwegian Social Research (NOVA) in the winter of 2001. The survey was intended to be nationally representative and sample selection used two-stage stratified random sampling. We have initially a sample of 1,900 households.

The survey collected information on the household and its constituent members, such as wealth, income, and employment status including attitudes to intergenerational relations. Both transfers given and transfers received were collected with a recall period covering the previous 12 months. The survey also collected information on educational attainment, the economic situation and other characteristics of the interviewed household member's parents and grown children.

For the purpose of our analysis, we use two different samples from the survey. One sample is confined to all respondents with grown children, except students. We call this the donor sample or donor dataset. Parents are asked about transfers given in the last 12 months to their children. Since each child-parent pair represents 
one observation, the number of observations in this sample $(1,337)$ is greater than the number of parent households (543). We have detailed information about the parent household, and information on each child as reported by the parent. The second sample consists of all respondents with at least one living parent. This is called the recipient sample or the recipient dataset (958 obs.). Grown children are asked about transfers received in the last 12 months from their parents, when there is at least one parent alive. In this dataset there is detailed information on the recipient household, who also report characteristics of the parents. Descriptive statistics for the two samples are reported in Table $1 .^{3}$

A gift is defined as any money transfer, payment of regular or extraordinary expenses, payment of travels/holidays, interest on loans or down payments on loans, and financial support through transferring cars/housing or in other ways allowing the children to make free use of cars/housing. According to Table 1, in 18 percent of the unique parent-child pairs the parents have transferred gifts to their grown children in the last 12 months. ${ }^{4}$ The conditional average value of these transfers is about NOK 31,000 (US $\$ 4,800$ ). For comparison, the average value of parent household income is NOK 324,000 (US\$ 50,300). The table also shows that 13 percent of the households report that they have received gifts in the last 12 months. The conditional average value of these gifts is NOK 24,000 (US\$ 3,720). ${ }^{5}$

\section{Parents show signs of being altruistic}

\subsection{Determinants of inter vivos gifts}

Before entering into closer examination of the trade-off between altruism and equal divisions (in Section 6), in this section we first (in Section 5.1) describe determinants of the transfer amount, using the two datasets: donors and recipients. Moreover, in Section 5.2 we probe deeper into explanations for unequal division behaviour by addressing information of children belonging to the same family. We will apply different econometric models to identify relationships. However, a general specification of the transfer function following from an altruistic model (see

\footnotetext{
${ }^{3}$ Students are omitted from the sample to avoid allowing transfers that can be regarded as investment in education to affects results. However, estimates with and without students in data show little difference, only smaller standard errors when they are included.

${ }^{4}$ While 27 percent of the parents have given to at least one of their children.

${ }^{5}$ We have no information that tells us if a gift has been reported to tax authorities as advancement of inheritance. In our sample, most of the gift amounts are lower than NOK 40,000 (US\$ 6,200), which we previously argued could be an unofficial limit of a gift that would have to be reported to the tax authorities. We have nonetheless decided to keep all information, and even gifts higher than NOK 40,000, considering that the tax law at the time of the survey was unclear about the limit for reporting a gift.
} 
Section 2) can be seen as

$$
b_{i j}=g\left(e_{j}, e_{i}, X, u_{i j}\right) \quad i=1, \ldots, N ; j=1, \ldots, P
$$

where $b_{i j}$ is the transfer to child $i$ from parent $j, e_{i}$ is the recipient/child income, $e_{j}$ is the donor/parent income, $X$ is a set of controls describing both donor and recipient household characteristics that contribute to determine transfer flows, and $u_{i j}$ is an error term capturing unobserved factors that influence transfer behaviour.

As is apparent from Table 1, more the majority of the surveyed households neither gave nor received transfers during the surveyed year. Parents may well end up with a corner solution with no transfers, which will explain some of the zero observations. Not observing transfers in data may also be due to the survey design, which implies that only gifts made or received over the last 12 months are included. Regardless of the explanation, ignoring the presence of the large number of zero values will result in the same type of biased inference as produced by censoring. A Tobit model is employed to account for the presence of nonparticipant households when analysing the transferred amount: ${ }^{6}$

$$
b_{i j}^{*}=\eta_{1} e_{j}+\eta_{2} e_{i}+X \boldsymbol{\beta}+u_{i j}
$$

where $\eta_{1}, \eta_{2}$ and $\beta$ are parameters and $b_{i j}^{*}$ is the latent transfer to child $i$,

$$
b_{i j}=\left\{\begin{array}{cll}
b_{i j}^{*} & \text { if } \quad b_{i j}^{*}>0 \\
0 & \text { if } \quad b_{i j}^{*} \leq 0
\end{array}\right.
$$

In addition, we present results of a standard Probit model estimation,

$$
\operatorname{Pr}\left(b_{i j}>0 \mid X\right)=\Phi\left(\theta_{1} e_{j}+\theta_{2} e_{i}+X \gamma\right),
$$

focusing on the determinants of positive transfers, not taking amounts into accounts as in the Tobit model. However, we expect to find similar results according to the two specifications. ${ }^{7}$

We estimate (8) and (9) using both the donor dataset and the recipient dataset. Since neither dataset has concurrent information about both donor and recipient income, we run two separate regressions. One shows estimation results based on

\footnotetext{
${ }^{6}$ This equation might be misspecified as it does not address the dependency between children of the same family; see further on for specifications to alleviate this problem.

${ }^{7}$ Alternatively, we tried to use a selection model to account for zero transfers. However, the results showed no evidence of the selection model performing better than the Tobit model (insignificant inverse Mill's ratio and a correlation between the error terms of the two equations close to zero). There may be several reasons for this. First, the variables that significantly affect the probability for a positive gift transfer being non-zero have the same sign as in a simple leastsquares regression on conditional gift amounts. Furthermore, theoretically there are no variables that we expect would only determine the choice to give and not the amount, and vice versa.
} 
information reported by the parents, where we have full information about the parents' income but only proxies for the child's income, such as educational level and whether the child is unemployed or a student. In the corresponding second regression we use information provided by the child, where we have full information about the child's income but only proxy information about the parents' income. For the parents, educational level of both parents and age has proved to be the best available proxies.

In the donor dataset there are $N$ number of children and $P(<N)$ number of parents, which means that some children (siblings) link up with the same parents. Thus, in the Tobit and Probit regressions, we adjust standard errors by assuming clustering by family. However, this feature opens up for a fixed effects approach, which controls for variables that are common to all siblings in a family. Consider the following equation for a transfer to child $k$ in family $j$

$$
b_{k j}=\beta Y_{k j}+v_{j}+\varepsilon_{k j},
$$

where $k=1, \ldots, 5$ and $j=1, \ldots, 543$. In (10) the elements of the vector $Y_{k j}$ are observed characteristics of the child that may vary between siblings. We include two unobserved components; one which is allowed to vary across parents and child $\left(\varepsilon_{k j}\right)$ and one unobserved family effect $\left(v_{j}\right)$. By adding fixed effects for each family, we are able to control for unobserved variables that are common to all siblings. The constant parental and family factors drop out of the estimated equation, and the fixed effects model is estimated by regressing the differences in sibling transfers on the differences in their indicator variables on economic situation.

Tables 2 and 3 reports Tobit and Probit estimates for inter vivos gifts given (donor dataset) and inter vivos gifts received (recipient dataset), respectively. Table 2 also reports results of the fixed effects regression.

Addressing the fixed effects estimation results first (see Table 2), the only variables that significantly affect the size of unequal transfers (at the 5 percent level) are the child's relative economic situation as evaluated by the parents, and the child's marital status. Parents pass on more gifts to a child that is worse off than her siblings, and a child that is single when its siblings are married. Being single indicates a considerably lower household income. Thus, we see indications of altruism. The estimates of the Tobit and Probit regressions in Table 2 are in accordance with this (except that the married/cohabitant variable becomes insignificant in the Tobit case).

Turning to the results of recipient dataset regressions, Table 3 also shows indications of altruistic behaviour: we see a significantly negative effect of recipient income on the amount of inter vivos gifts, and the Probit estimate give support for a negative relationship. This confirms the standard hypothesis that a child with low income will receive a larger transfer from her parents than a child with 
Table 2: Donor data: determinants of inter vivos gifts

\begin{tabular}{|c|c|c|c|c|c|c|}
\hline \multirow{2}{*}{$\begin{array}{l}\text { Dependent variable: } \\
\text { Gifts given last } 12 \text { months }\end{array}$} & \multicolumn{2}{|c|}{ Tobit } & \multicolumn{2}{|c|}{ Probit } & \multicolumn{2}{|c|}{ Fixed effects } \\
\hline & Coef. & S.E. ${ }^{a}$ & $\begin{array}{l}\text { Marg. } \\
\text { effect }\end{array}$ & S.E. ${ }^{a}$ & Coef. & S.E. \\
\hline \multicolumn{7}{|l|}{ Parent characteristics } \\
\hline Household income ${ }^{b}$ & .113 & .035 & .041 & .008 & - & - \\
\hline Household net wealth ${ }^{b}$ & .018 & .003 & .003 & .000 & - & - \\
\hline Age & -.820 & .697 & -.001 & .002 & - & - \\
\hline Couple & 10.3 & 22.7 & .062 & .052 & - & - \\
\hline Number of children & -33.9 & 8.13 & -.065 & .016 & - & - \\
\hline College/university, father & 16.0 & 13.6 & .013 & .031 & - & - \\
\hline College/university, mother & 33.3 & 14.2 & .086 & .033 & - & - \\
\hline \multicolumn{7}{|l|}{ Child characteristics } \\
\hline Household income & - & - & - & - & - & - \\
\hline Female & -6.08 & 10.6 & -.024 & .022 & 1.57 & 2.04 \\
\hline Married/cohabitant & -25.7 & 19.6 & -.130 & .048 & -13.8 & 4.52 \\
\hline College/university & 7.55 & 11.8 & .016 & .023 & .787 & 2.61 \\
\hline Grandchildren & -1.65 & 13.1 & -.012 & .027 & -1.55 & 2.66 \\
\hline Unemployed & -.154 & 21.9 & -.026 & .042 & -4.62 & 5.07 \\
\hline Economic situation: bad & 61.2 & 21.8 & .368 & .087 & 14.4 & 3.90 \\
\hline Economic situation: well & -28.2 & 11.5 & -.042 & .024 & -3.25 & 2.63 \\
\hline se & 107.7 & 6.45 & & & & \\
\hline$E \operatorname{Pr}\left[b_{i j}>0\right]$ & \multicolumn{6}{|c|}{.15} \\
\hline Log likelihood & \multicolumn{2}{|c|}{$-1,243$} & \multicolumn{2}{|c|}{-443} & \multirow{2}{*}{\multicolumn{2}{|c|}{0.44}} \\
\hline Pseudo $R^{2} /$ Within $R^{2}$ & \multicolumn{2}{|c|}{0.05} & \multicolumn{2}{|c|}{0.18} & & \\
\hline Number of obs. (no of fam) & \multicolumn{2}{|c|}{1,337} & \multicolumn{2}{|c|}{1,337} & \multicolumn{2}{|c|}{$1,337(543)$} \\
\hline
\end{tabular}


Table 3: Recipient data: determinants of inter vivos gifts

\begin{tabular}{|c|c|c|c|c|}
\hline \multirow{2}{*}{$\begin{array}{l}\text { Dependent variable: } \\
\text { Gifts received last } 12 \text { months }\end{array}$} & \multicolumn{2}{|c|}{ Tobit } & \multicolumn{2}{|c|}{ Probit } \\
\hline & Coef. & S.E. & $\begin{array}{l}\text { Marg. } \\
\text { effect }\end{array}$ & S.E. \\
\hline \multicolumn{5}{|l|}{ Parent characteristics } \\
\hline Household income & - & - & - & - \\
\hline Household net wealth & - & - & - & - \\
\hline Age & -.977 & .316 & -.003 & .001 \\
\hline Couple & 4.14 & 8.37 & .009 & .022 \\
\hline Number of children & -4.38 & 2.16 & -.012 & .007 \\
\hline College/university, father & 2.72 & 6.79 & .046 & .027 \\
\hline College/university, mother & 17.9 & 7.08 & .044 & .029 \\
\hline \multicolumn{5}{|l|}{ Child characteristics } \\
\hline Household income ${ }^{a}$ & -.047 & .019 & -.017 & .007 \\
\hline Female & -1.29 & 4.65 & -.009 & .022 \\
\hline Married/cohabitant & -6.64 & 5.99 & -.027 & .021 \\
\hline College/university & 11.9 & 6.31 & .061 & .023 \\
\hline Grandchildren & -7.22 & 6.59 & -.040 & .024 \\
\hline Unemployed & 2.85 & 9.31 & .028 & .036 \\
\hline Economic situation: bad & .432 & 10.1 & .031 & .040 \\
\hline Economic situation: well & -10.5 & 6.63 & -.052 & .024 \\
\hline se & 55.7 & 3.91 & & \\
\hline$E \operatorname{Pr}\left[b_{i j}>0\right]$ & \multirow{2}{*}{\multicolumn{2}{|c|}{-913}} & \multicolumn{2}{|c|}{.120} \\
\hline Log likelihood & & & \multicolumn{2}{|c|}{-347} \\
\hline Pseudo $R^{2}$ & \multicolumn{2}{|c|}{0.04} & \multicolumn{2}{|c|}{0.12} \\
\hline Number of obs. & \multicolumn{2}{|c|}{958} & \multicolumn{2}{|c|}{958} \\
\hline
\end{tabular}


high income, all other things equal. We replaced the child's household income with household income per person, without affecting the results. Further, parents' income and wealth have the expected positive sign. However, the size of the coefficients is small, the estimate of the recipient income derivative is only around -.05. The estimates are also small in view of the transfer-income derivative restriction. ${ }^{8}$ It is not the objective of this analysis to provide estimates for this restriction, as it (ideally) requires detailed information about parents and children under changing conditions. However, in order to show magnitudes of the estimates, in Appendix $\mathrm{B}$ we present results in terms of components of the restriction. There we also apply more sophisticated methods to account for selectivity. ${ }^{9}$ Note also that this estimate does not rule out other transfer motives, such as the exchange motive.

A positive estimate for the effect of parents household income (see Tobit estimation in 2) is also in accordance with expectations. Effects of other donor characteristics are basically the same, irrespective of whether the donor dataset or the recipient dataset is used. The transfer declines as the parent household ages, where age is set equal to the mother's age in the recipient data set. It makes no difference for the results whether we consider the child's age or the parent's age. Descriptive statistics show that transfers are smaller and more frequent when children are younger, and conversely larger and less frequent when parents and children are older. High education of both mother and father has a positive effect on the size of a transfer, but note that having a mother with high education affects the size and probability of a positive gift more than having a father with high education, especially in the donor data.

\subsection{Within families evidence}

As already noted, one of the advantages of the donor dataset is the opportunity it gives to compare siblings directly. Here, we use this feature to study unequal treatment behaviour more directly, by conditioning on families where at least one of the siblings has received an inter vivos gift from his or her parents; in contrast to the family fixed effects of Table 2, where all families entered into the dataset. Also, the within family approach followed so far does not open up for unequal

\footnotetext{
${ }^{8}$ Recall that a unit's increase in parental income combined with a unit's decrease in child income should yield a transfer response of one unit $\left(\eta_{1}-\eta_{2}=1\right)$, as discussed in Section 2 .

${ }^{9}$ Altonji et al. (1997) argue that traditional methods to account for sample selectivity, such as the Tobit model, can give misleading results when testing the transfer-income derivative restriction. The reason is that the restriction holds only for $b_{i}>0$, and this selection rule implies that transfers to well-off children (which occur) will bias against altruism. Moreover, as altruism is only observed through the transfer-income derivative, and therefore is not separable from incomes, there is no easy way to control for this selectivity problem. We refer to Appendix B for estimates when employing the Altonji-Ichimura method (Altonji and Ichimura, 2000) to control for selectivity.
} 
Table 4: Distribution of siblings and number of families in the sibling sample

\begin{tabular}{lrrr}
\hline \hline Siblings & $\begin{array}{r}\text { No of children/ } \\
\text { observations }\end{array}$ & $\begin{array}{r}\text { No of parents/ } \\
\text { families }\end{array}$ & $\begin{array}{r}\text { Fraction of families } \\
\text { with unequal divisions }\end{array}$ \\
\hline 2 & 144 & 72 & 0.59 \\
3 & 102 & 34 & 0.84 \\
4 & 24 & 6 & 0.83 \\
5 & 5 & 1 & 1.00 \\
Total & 275 & 113 & 0.72 \\
\hline
\end{tabular}

${ }^{a}$ Deviation larger than 10 percent from exact equal sharing.

transfers being explained by donor characteristic, whereas it is possible that the parents' income, educational level and number of children may be determinants of the choice to share unequally between children. An alternative approach is therefore to use the information about parents to control for the number of zeros in the dependent variable by applying a selection model (Heckman, 1979). ${ }^{10}$

The Heckman selection model allows us to regress the determinants of unequal sharing among siblings

$$
b_{k j}-\bar{b}_{j}=\alpha\left(y_{k j}-\bar{y}_{j}\right)+\left(\varepsilon_{k j}-\bar{\varepsilon}_{j}\right),
$$

when the probability of a gift being unequally shared follows from a separate equation

$$
\operatorname{Prob}(g=1)=\Phi\left(\theta Z_{j}+\zeta Y_{k j}\right), \text { where } g=1 \text { if } 0.9>\frac{b_{k j}}{\bar{b}_{j}}>1.1
$$

i.e. the probability of unequal sharing is conditional on a gift being given that deviate more than 10 percent from exact equal sharing. $Z_{j}$ is a vector of parental characteristics that is likely to influence the decision to divide gifts unequally. The composition of siblings and number of families is presented in Table 4. We see that there are unequal divisions in many families; the argument of this paper is that we would have seen more of it, if parents do not have a desire for dividing equally too.

The results are presented in Table 5. The first column of the table presents results for the Probit equation, whereas results of the second stage are presented

\footnotetext{
${ }^{10}$ By employing the selection model instead of the Tobit model used in Section 4.3, we allow the coefficients in the probability equation to have different signs from the coefficients in the OLS equation. Also, to approach the problem by a Tobit model is not meaningful, since the construction of the dependent variable, difference in gifts, yields both positive and negative values.
} 
Table 5: Results for the probability and determinants of unequal sharing

\begin{tabular}{|c|c|c|c|c|}
\hline & \multicolumn{2}{|c|}{ Probit (1st stage) } & \multicolumn{2}{|c|}{ OLS (2nd stage) $)^{a}$} \\
\hline & Coef. & S.E. & Coef. & S.E. \\
\hline \multicolumn{5}{|l|}{ Parent characteristics } \\
\hline Household income ${ }^{b}$ & -.291 & .088 & - & - \\
\hline Couple & .884 & .375 & - & - \\
\hline College/university, father & .470 & .421 & - & - \\
\hline College/university, mother & .035 & .397 & - & - \\
\hline Number of children & .961 & .278 & - & - \\
\hline \multicolumn{5}{|l|}{ Child characteristics } \\
\hline Economic situation & 1.09 & .320 & -8.06 & 2.14 \\
\hline Unemployed & -.048 & .607 & 6.12 & 3.20 \\
\hline Age & -.016 & .020 & -.567 & .381 \\
\hline Sex & -.163 & .300 & -.039 & 2.42 \\
\hline Married/cohabitant & -.869 & .524 & 3.32 & 3.20 \\
\hline Educational level & -.613 & .324 & 1.82 & 2.93 \\
\hline Grandchildren & -.359 & .370 & -1.66 & 3.40 \\
\hline$\lambda$ & & & 6.02 & 3.25 \\
\hline$\rho$ & \multicolumn{4}{|c|}{$.62(.31)$} \\
\hline Censored observations & \multicolumn{4}{|c|}{29} \\
\hline No of observations & \multicolumn{4}{|c|}{162} \\
\hline
\end{tabular}

${ }^{a}$ Dependent/independent variables are measured as deviation of the child's gift/characteristic from the sibling mean.

${ }^{b}$ in NOK 1,000

in the second column. The coefficients of the Probit equation show that the probability of unequal sharing declines significantly with parents' household income. It is reasonable to interpret this as high-income parents more easily avoiding the trade-off between compensating one child and treating all their children equally, by giving equally to all when only one child really needs the gift. Also, if the parent is single it is more likely that the gift is shared equally among children, probably since these gifts are intended as advancement of inheritance. The estimation also indicates that the probability of unequal sharing increase with the number of children. This is probably partly due to the limited observation period of 12 months.

According to the second stage OLS regression, it is only the relative economic 
situation of a child that significantly affects how much unequal transfers the child receives when the probability of unequal sharing is controlled for. The negative coefficient reflects that the sibling who is better off receives a smaller transfer. Thus, again we find signs of altruism. At a lower significance level we find that older children get less than their younger siblings.

The evidence presented in this section indicate that parents behave in accordance with altruism: the only consistently significant determinant of unequal sharing across specifications is the child's economic situation relative to its siblings. However, even though we find that parents behave altruistically, we have also established that effects are small. We assume that the reason is that parents also want to divide equally. In the next section we discuss this further.

\section{Testing hypotheses about transfer behaviour under competing motives}

\subsection{More altruism in one-child families}

The regression results of Section 5 forms the background for probing deeper into explanations for the rather small effect with respect to equalisation between children. In Section 2 we discussed a modification of the altruism model, under the assumption that parents with more than one child face a trade-off between compensating one child's income and giving equally to all children. We would therefore expect the income compensation to be smaller in families with two or more adult children than in families with only one child. In this perspective, signs of (pure) parental altruism, such as the finding evidence in accordance with the transferincome derivative restriction, is more realistically obtained in one-child families, as these parents do not have to struggle with their desires for equal divisions. In this section we assess to what extent the recipient income derivative, $\partial b_{i} / \partial e_{i}$, is larger in one-child families.

Table 6 presents results of separate regressions for families with one child and families with two or more children, employing Tobit estimation and the recipient data set. The last two columns show that the overall estimate of the recipient income derivative is -.05 . Table 6 shows a big difference in the estimated transfer derivative, dependent on number of children: -.32 for one-child families, and only -.04 for children with siblings. The difference between the two is significant at a 5 percent significance level, confirming the hypothesis that an only child receives more income compensation from her parents, indicating the effect of preferences for equal division, competing with "purely" altruistic motives. More altruism in onechild families is also in accordance with findings in Wilhelm (1996) with respect to bequests, but he relates this to a weaker exchange motive in such families. 
Table 6: Estimation results for inter vivos gifts by number of children. Tobit estimation, recipient dataset

\begin{tabular}{|c|c|c|c|c|c|c|}
\hline & \multicolumn{2}{|c|}{$\begin{array}{c}\text { Recipients } \\
\text { with no } \\
\text { siblings }\end{array}$} & \multicolumn{2}{|c|}{$\begin{array}{c}\text { Recipients } \\
\text { with one or } \\
\text { more siblings }\end{array}$} & \multicolumn{2}{|c|}{ All } \\
\hline & Coef. & S.E. & Coef. & S.E. & Coef. & S.E. \\
\hline \multicolumn{7}{|l|}{ Parent characteristics } \\
\hline Age & .663 & .903 & -1.02 & .237 & -.977 & .316 \\
\hline Couple & -1.10 & 36.0 & 3.32 & 4.98 & 4.14 & 8.37 \\
\hline Number of children & - & - & -4.21 & 1.91 & -4.38 & 2.16 \\
\hline College/university, father & -18.5 & 18.0 & 5.17 & 5.67 & 2.71 & 6.79 \\
\hline College/university, mother & 65.3 & 22.7 & 13.7 & 5.79 & 17.9 & 7.08 \\
\hline \multicolumn{7}{|l|}{ Child characteristics } \\
\hline Household income $^{a}$ & -.316 & .093 & -.038 & .016 & -.047 & .019 \\
\hline Female & -1.91 & 18.5 & -7.78 & 4.91 & -1.29 & 4.65 \\
\hline Married/cohabitant & 30.8 & 26.9 & -10.9 & 6.39 & -6.64 & 5.99 \\
\hline College/university & 33.9 & 17.9 & 10.8 & 5.20 & 11.9 & 6.31 \\
\hline Grandchildren & 7.96 & 21.5 & -7.88 & 5.36 & -7.22 & 6.59 \\
\hline Unemployed & - & - & 4.29 & 6.74 & 2.85 & 9.31 \\
\hline Economic situation: bad & -54.1 & 36.0 & 4.10 & 7.51 & .432 & 10.1 \\
\hline Economic situation: well & -7.73 & 27.5 & -9.54 & 5.52 & -10.5 & 6.63 \\
\hline se & 32.4 & 7.45 & 56.7 & 2.99 & 55.7 & 3.91 \\
\hline Log likelihood & \multicolumn{2}{|c|}{-63.1} & \multicolumn{2}{|c|}{-842.1} & \multicolumn{2}{|c|}{-913} \\
\hline Pseudo $R^{2}$ & \multicolumn{2}{|c|}{0.16} & \multicolumn{2}{|c|}{0.04} & \multicolumn{2}{|c|}{0.04} \\
\hline Number of observations & \multicolumn{2}{|c|}{56} & \multicolumn{2}{|c|}{902} & \multicolumn{2}{|c|}{958} \\
\hline
\end{tabular}


Figure 1: Fitted spline for inter vivos gifts by recipient household income

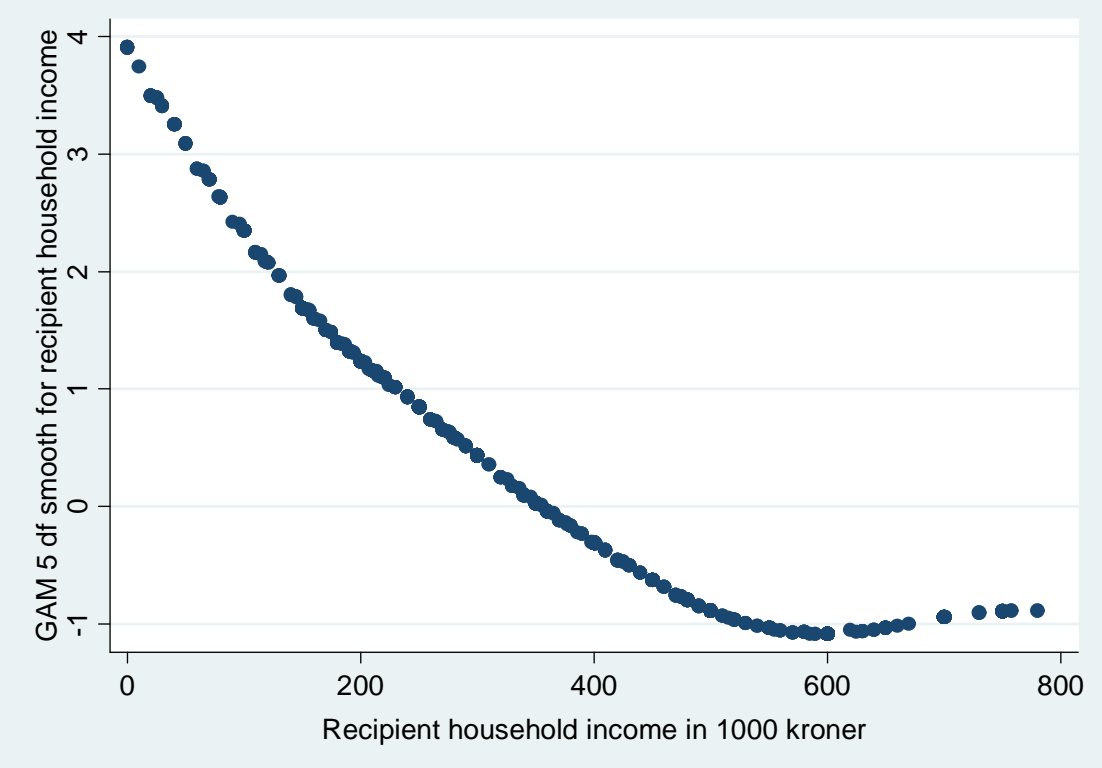

Even though the estimated transfer derivatives for recipient income do differ, depending on the number of children, it should be noted that the number of observations is low in the sub-sample of one-child families. Note also that all other explanatory variables are insignificant in the regression results reported in the first two columns, except recipient income and the dummy for mothers with college/university degree.

\subsection{Nonlinearity in the response to child income}

As stated above, parents that weigh altruism against equal division considerations might be involved in unequal gift behaviour when differences between children exceed a certain level. In other words, parents will only compensate a child with an income substantially below the sibling average. Under this hypothesis we will find more compensating behaviour among recipients at low income levels, because there we expect to find children there with much lower income, compared to their siblings. Letting the expected level of income be represented by mean or median income, children at low levels of income will presumably both differ substantially from their siblings and they will be in greater need for assistance.

Graphically we investigate this hypothesis by using a semiparametric regression method, which has the advantage of not imposing any restrictions on the functional 
form when relating income to gift amounts. The profile in Figure 1 is a fitted spline to the variable recipient household income, whereas the parametric part of the equation consists of the other variables in the model. According to the figure, inter vivos gifts seems to be negatively related to household incomes lower than NOK 500,000 (US\$ 77,520), and approximately flat or zero for incomes above that level. If we compare this to the average income in recipient households, which is NOK 420,000 (US\$ 65,120) in the sample, we find that a child's income is negatively related to transfers when the child has lower than average income when the child has lower than average income.

In light of the plot in Figure 1 the transfer derivative could probably be approximated by a piecewise linear function, where the transfer derivative is allowed to change at the lower quartile (NOK 250,000; US\$ 38,760) and the upper quartile (NOK 550,000; US\$ 85,270) of the recipient income distribution. Table 7 shows the results of replacing recipient income with a piecewise linear function defined as

$$
\begin{aligned}
& \text { low income }=\begin{array}{cl}
e_{i} & \text { if } e_{i} \leq 250 \\
250 & \text { if } e_{i}>250
\end{array} \\
& 250 \text { if } e_{i} \leq 250 \\
& \text { medium income }=e_{i} \quad \text { if } 250<e_{i} \leq 550 \\
& 550 \text { if } e_{i}>550 \\
& \text { high income }=\begin{array}{cl}
550 & \text { if } e_{i} \leq 550 \\
e_{i} & \text { if } e_{i}>550
\end{array}
\end{aligned}
$$

The sample used is child respondents with siblings where explanatory variables other than income are the same as in Table 6 . Table 7 shows that allowing recipient income to spread out at the low end of the income distribution (as obtained by the low income spline), generates more equalisation, as indicated by the parameter estimates: -0.16 for low-income households and zero for high-income households. Given the size of the standard errors, the estimated coefficients for the three income segments in Table 7 are not significantly different from each other. However, it yields a strong indication of a non-linear relationship between transfers and recipient income. Alternatively, we could have chosen median household income as the knot. The estimated transfers derivatives would then have been -.10 (.02) for incomes lower than the median and -.02 (.03) for incomes above the median (with standard errors in parentheses). For incomes above the mean or median income in the sample, the relationship between gifts and income is not significantly different from zero.

Cox, Hansen and Jimenez (2004) also find a non-linear relationship when using data from the Philippines, but they offer a different interpretation; arguing that 
Table 7: Tobit results with non-linear transfer response to income

\begin{tabular}{llc}
\hline \hline & \multicolumn{2}{c}{ Two or more children } \\
& Coef. & S.E. \\
\hline Low household income $^{b}(<250)$ & -.155 & .075 \\
Medium household income $^{b}(250-550)$ & -.012 & .037 \\
High household income $^{b}(>550)$ & -.007 & .065 \\
Controls $^{a}$ & & \\
$s e$ & 56.5 \\
Log likelihood & -840 \\
Pseudo $R^{2}$ & 0.04 \\
Number of observations & 902 \\
\hline${ }^{a}$ Same control variables for parent and child characteristics as in Table 6. \\
${ }^{b}$ In NOK 1,000
\end{tabular}

exchange motives dominate altruism above a threshold level. ${ }^{11}$ In our interpretation, parents with more than one child face a trade off between a child's need and also wanting to divide equally. When the income of a child is above average, we assume the economic situation of the child is adequate, and parents can give preference to equal sharing.

\section{$7 \quad$ Reported attitudes}

The survey also asked about attitudes towards intergenerational transfers and motives for transfers, similar to the evidence reported by Light and McGarry (2004). Since our claim is based on an assumption of parents' attitude to fairness, it would be useful to see how they stand on these questions. The question "What kind of economic obligations do you think parents should have towards their grown children?" can be related to the degree of altruism since the response alternatives range from "they should be helped only in emergencies" to "they should be helped so that they may attain the same living standard as their parents". As shown in Table 8, a majority of the parents believe children should only be helped in emergencies. The group of parents actually transferring resources to their children in the survey period is identified as "transfer parents" and the table shows that they are somewhat more inclined to agree about giving children help for purposes of education, house purchase and starting a family, but the difference between those who transfer and the rest is small.

\footnotetext{
${ }^{11}$ A non-linear relationship is also noted by other authors, such as Schoeni (1997).
} 
Table 8: Parents' attitudes to inter vivos transfers

\begin{tabular}{|c|c|c|}
\hline \multicolumn{3}{|c|}{$\begin{array}{l}\text { What kind of economic obligation do you think } \\
\text { parents should have towards their grown children? }\end{array}$} \\
\hline Only in emergencies & .68 & .64 \\
\hline Education, house and family formation & .26 & .33 \\
\hline Same living standard as parents & .04 & .02 \\
\hline \multicolumn{3}{|c|}{$\begin{array}{l}\text { When parents that have more than one child give economic support, } \\
\text { how do you think they should divide the resources? }\end{array}$} \\
\hline & All parents & Transfer parents \\
\hline Equal sharing & .73 & .67 \\
\hline According to need & .23 & .29 \\
\hline To the most helpful child & .01 & .02 \\
\hline To the most able child & .00 & .01 \\
\hline No of observations & 543 & 147 \\
\hline
\end{tabular}

In the present study we employ information on gifts given in the last 12 months. As already noted, tests of transfer motives should ideally be carried out with lifecycle information about transfers from parents to children, also linking siblings to the parents. The dataset do have information about previous transfers in the form of questions to the parents about whether they have ever: a) given support to a child's education, b) helped them buy a house, or c) provided an advance of their inheritance. Questions like these open up a new set of problems since the answers depend on the parents' age (inheritance advances in particular); we therefore use this information cautiously. We nevertheless note that 50 percent of the parents had helped their children get an education and 26 percent had helped to buy a house. Comparing these figures with the 26 percent who believed in helping children to get an education, there seems to be a discrepancy between theory and practice.

A related question was: "When parents with more than one child want to help them economically, how do you think they should divide the money between them?" Table 8 shows that the majority prefer equality. Very few answer that they would want the most helpful child or able/talented child to be treated preferentially. Although a sizeable number believes in preferentially helping the child in most need, equal sharing does seem to be the general norm. The stated preferences can be checked against the transfer behaviour. Among parents with more than one child, 45 percent believed they had shared equally between them. Calculations of 
actual behaviour from data show that only about 30 percent approximated equal sharing (within 10 percent of exactly equal sharing). Again there is a discrepancy between theory and practice. We conclude that equal sharing, while often the stated norm, seems difficult to practice when parents face the needs or merits of the children.

\section{Concluding remarks}

As discussed for instance by Gale and Slemrod (2000) and Kaplow (2001), an inheritance tax is expected to distort behaviour when parents are altruistic. If parents behave in accordance with the altruism model, taxes on intergenerational transfers are likely to deplete donors' savings and lower the incentive to work. No such harmful tax effects on donors' behaviour exist if bequests are unintended, that is, follow from death before donors have been able to consume all their wealth.

In this perspective it is of key importance to interpret parents' transfer behaviour. It is often found that bequests are divided equally, which may support the view that bequests are unintentional and therefore can be taxed with less distortive effects. However, it has been argued that equally divided bequests follow from psychic costs of unequal treatment (Wilhelm, 1996) or from parental affection (Bernheim and Severinov, 2003). Here, the main point has been that parents want to divide equally, as they are inequality averse, but that this ambition competes with altruism. Since Norwegian transmission laws and incentives following from the inheritance tax, limit the scope for finding altruism with respect to bequests and taxable gifts, we analyse how non-taxable gifts are transferred.

Our results suggest that parents both would like to divide equally and be altruistic. If parents divide unequally to their children, they will support the child that they believe has a difficult economic situation. But we also find support for parents' preferences for equal divisions, as the recipient income derivative is significantly higher in one-child families than in multiple child families and by finding that the income derivative in multiple child families is non-linear, with a larger degree of parental compensation of income when the child's income is lower than mean or median income. Parents' self-reported motives for transfers to children also suggest that dividing equally is important.

\section{References}

[1] Altonji, J.G., F. Hayashi and L.J. Kotlikoff (1997): Parental Altruism and Inter Vivos Transfers: Theory and Evidence, Journal of Political Economy $105,1121-1166$. 
[2] Altonji, J.G, and H. Ichimura (2000): Estimating Derivatives in Nonseparable Models with Limited Dependent Variables, mimeo, Northwestern University.

[3] Arrondel, L. and A. Laferrère (2001): Taxation and Wealth Transmission in France, Journal of Public Economics 79, 3-33.

[4] Arrondel L. and A. Masson (2006): "Altruism, Exhange or Indirect reciprocity: What do the Data on Family Transfers Show?", in S.-C. Kolm and J.M. Ythier (eds.): Handbook of the Economics of Giving, Altruism and Reciprocity, Volume 2, Amsterdam: Elsevier/North-Holland, 971-1053.

[5] Barro, R.J. (1974): Are Government Bonds Net Wealth?, Journal of Political Economy 82, 1095-1117.

[6] Becker, G.S. (1974): A Theory of Social Interactions, Journal of Political Economy 82, 1063-1093.

[7] Becker, G.S. and N. Tomes (1979): An Equilibrium Theory of the Distribution of Income and Intergenerational Mobility, Journal of Political Economy 87, 1153-89.

[8] Behrman, J., R. Pollak and P. Taubman (1982): Parental Preferences and Provision for Progeny, Journal of Political Economy 90, 52-73.

[9] Bernheim, B.D. and S. Severinov (2003): Bequests as Signals: An Explanation for the Equal Division Puzzle, Journal of Political Economy 111, 733-764.

[10] Bernheim, B.D., A. Shleifer and L.H. Summers (1985): The Strategic Bequest Motive, Journal of Political Economy 93, 1045-76.

[11] Bruce, N., and M. Waldman (1990): The Rotten-Kid Theorem Meets the Samaritan's Dilemma, Quarterly Journal of Economics 105, 155-165.

[12] Cox, D. (1987): Motives for Private Income Transfers, Journal of Political Economy 95, 508-546.

[13] Cox, D., B.E. Hansen, and E. Jimenez (2004): How Responsive are Private Transfers to Income? Evidence from a Laissez-Faire Economy, Journal of Public Economics 88, 2193-2219.

[14] Cox, D. and M.R. Rank (1992): Inter Vivos Transfers and Intergenerational Exchange, Review of Economics and Statistics 74, 305-314.

[15] Davies, J.B. (1981): Uncertain Lifetime, Consumption, and Dissaving in Retirement, Journal of Political Economy 89, 561-577. 
[16] Dunn, T.A. and J.W. Phillips (1997): The Timing and Division of Parental Transfers to Children, Economics Letters 54, 135-137.

[17] Gale, W.G. and J.B. Slemrod (2000): Life and Death Questions about the Estate and Gift Tax, National Tax Journal 53, 889-912.

[18] Heckman, J. (1979): Sample Selection Bias as a Spesification Error, Econometrica 47, 153-161.

[19] Kaplow, L. (2001): "A Framework for Assessing Gift and Estate Taxation", in W.G. Gale, J.R. Hines Jr. and J. Slemrod (eds.): Rethinking Estate and Gift Taxation, Washington D.C: Brookings Institution Press, 164-204.

[20] Laferrère, A. and F.-C. Wolff (2006): "Microeconomic Models of Family Transfers", in S.-C. Kolm and J.M. Ythier (eds.): Handbook of the Economics of Giving, Altruism and Reciprocity, Volume 2, Amsterdam: Elsevier/NorthHolland, 889-970.

[21] Laitner, J. and H. Ohlsson (2001): Bequest Motives: a Comparison of Sweden and the United States, Journal of Public Economics 79, 205-236.

[22] Light, A. and K. McGarry (2004): Why Parents Play Favorites: Explanations for Unequal Bequests, The American Economic Review 94, 1669-1681.

[23] Lundholm, M. and H. Olsson (2000): Post Mortem Reputation, Compensatory Gifts and Equal Bequests, Economics Letters 68, 165-171.

[24] McGarry, K. (1999): Inter Vivos Transfers and Intended Bequests, Journal of Public Economics 73, 321-351.

[25] McGarry, K. (2000): Testing Parental Altruism: Implications of a Dynamic Model, NBER Working Paper No. W7593.

[26] Menchik, P.L. (1988): "Unequal Estate Division: Is It Altruism, Reverse Bequests, or Simply Noise", in D. Kessler and A. Masson (eds.): Modelling the Accumulation and Distribution of Wealth, New York: Oxford University Press, 105-116.

[27] The Ministry of Finance (2000): NOU 2000:8 Arveavgift, Oslo: Akademika (In Norwegian).

[28] Poterba, J. (2001): Estate and Gift Taxes and Incentives for Inter Vivos Giving in the US, Journal of Public Economics 79, 237-264. 
[29] Pestieau, P. (2003): "The Role of Gift and Estate Transfers in the United States and in Europe", in A.H. Munnell and A. Sunden (eds.): Death and Dollars. The Role of Gifts and Bequests in America, Washington D.C.: Brookings Institution Press, 64-85.

[30] Schoeni, R.F. (1997): Private Interhousehold Transfers of Money and Time: New Empirical Evidence, Review of Income and Wealth 43, 423-448.

[31] Stark, O. (1998): Equal Bequests and Parental Altruism: Compatibility or Orthogonality?, Economics Letters 60, 161-171.

[32] Villanueva, Ernesto (2002): Parental Altruism under Imperfect Information: Theory and Evidence, Economics Working Papers 650, Department of Economics and Business, Universitat Pompeu Fabra.

[33] Wilhelm, M.O. (1996): Bequest Behavior and the Effect of Heir's Earnings: Testing the Altruistic Model of Bequests, American Economic Review 86, 874-892. 


\section{A The Norwegian inheritance tax system}

The Norwegian inheritance tax system is based aggregation of gifts (over the yearly tax-free amount) and bequests to establish the tax base. Spouses are considered as two donors, which means that the value of an asset that is owned by both parents (matrimonial asset) is divided into two parts, one for each parent, when calculating the tax base. As shown in the figure, the inheritance tax rate scheme implies that inheritances below NOK 250,000 (US\$ 39,000) is tax exempt, while a two-tier rate system applies to inheritances above that, commencing at a rate of 8 percent, while transfers above NOK 550,000 (US\$ 85,000) are taxed at a rate of 20 percent. This scheme also applies to parents of the deceased.

Table A.1 The Norwegian inheritance tax scheme, 2003.

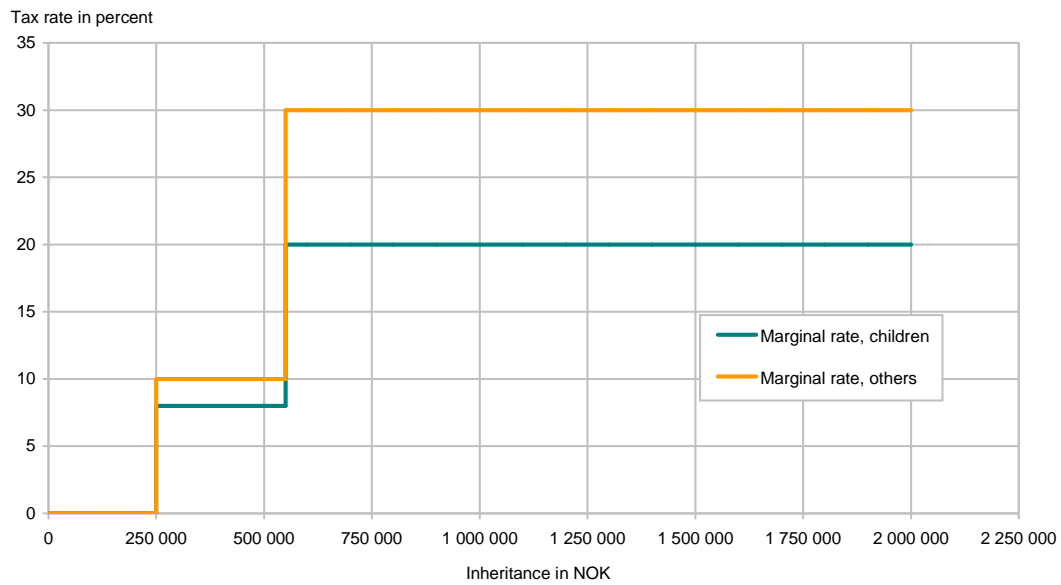

The figure also shows that the rates for other relatives and other heirs under a will are 10 percent and 30 percent in the two brackets, respectively. Inter-spousal gifts and bequests are not taxed. The general valuation rule is that assets should be valued at the market value. However, there are some important exemptions. For non-listed shares and interests in partnerships, firstly, the value of the company is calculated by excluding values of most intangible assets, as goodwill, by setting real estate values very low, and, secondly, only 30 percent of the total value is included in the tax base. The main purpose of this rule is to facilitate the transfer of family businesses. However, because of the tax avoiding behaviour such rules induce, the schedule will most likely be changed in the future, involving rate cuts in exchange of base broadening. Note also that there are incentives to report low values, as taxation in most cases is based on values reported by tax-payers to tax authorities. 


\section{B The AI estimator and the transfer-income deriv- ative restriction}

Based on Altonji and Ichimura (2000), relying on the assumption that the distribution of altruism is independent of incomes and other explanatory variables, Altonji et al. (1997) suggest to correct derivatives directly:

$$
\left(\frac{\partial b}{\partial e_{p}}-A_{p}\right)-\left(\frac{\partial b}{\partial e_{i}}-A_{i}\right)=1
$$

where

$$
\begin{aligned}
A_{p} & =\frac{-\partial P_{b}(Z)}{\partial e_{p}} \frac{\bar{b}(Z)}{P_{b}}, \quad A_{i}=\frac{-\partial P_{b}(Z)}{\partial e_{i}} \frac{\bar{b}(Z)}{P_{b}} \\
\bar{b}(Z) & =E[b(Z) \mid Z, b>0], \text { and } P_{b}=P[b>0 \mid Z] .
\end{aligned}
$$

$Z$ denotes explanatory variables corresponding to $X$ in equation (8). However, in order to make the function more flexible we introduce a third degree polynomial in income and age. It should be noted that we find some variations in estimates dependent on which variables that enter into the polynoms. When using this estimation strategy, the corresponding estimates for the parents' income derivative, $\hat{\eta}_{1}$, is 0.18 and the child's income derivative, $\hat{\eta}_{2}$, is -0.044 , which gives an estimate of the transfer-income derivative restriction of 0.22 .

There are several factors that may potentially account for this small estimate. In the present paper, we focus on preferences for equal divisions. There may be other explanations, for instance, parents may be uncertain about their own future income, in particular if they have not yet reached retirement. Parents may also be uncertain about their children's future income, and use current income as a signal of future income. McGarry (2000) suggests that transfers from altruistic parents will not react much to a drop in current income, since a drop in current income leads parents to modify the expected future income of the child, and thus anticipate a need for higher transfers in the future.

Asymmetric information may also contribute to small estimates. According to Villanueva (2002) parents may observe the income of their children, but observe neither the labor market opportunities nor the effort of their children. In this setting, parents face a trade-off when deciding about the optimal amount of help to give to their children. For analysis of detrimental effects of transfers, see also discussions of the Samaritan's dilemma, as in Bruce and Waldman (1990). 


\section{CESifo Working Paper Series}

for full list see www.cesifo-group.org/wp

(address: Poschingerstr. 5, 81679 Munich, Germany, office@cesifo.de)

2409 Alexander Kemnitz, Native Welfare Losses from High Skilled Immigration, September 2008

2410 Xavier Vives, Strategic Supply Function Competition with Private Information, September 2008

2411 Fabio Padovano and Roberto Ricciuti, The Political Competition-Economic Performance Puzzle: Evidence from the OECD Countries and the Italian Regions, September 2008

2412 Joan Costa-Font and Mireia Jofre-Bonet, Body Image and Food Disorders: Evidence from a Sample of European Women, September 2008

2413 Thorsten Upmann, Labour Unions - To Unite or to Separate?, October 2008

2414 Sascha O. Becker and Ludger Woessmann, Luther and the Girls: Religious Denomination and the Female Education Gap in $19^{\text {th }}$ Century Prussia, October 2008

2415 Florian Englmaier and Stephen Leider, Contractual and Organizational Structure with Reciprocal Agents, October 2008

2416 Vittorio Daniele and Ugo Marani, Organized Crime and Foreign Direct Investment: The Italian Case, October 2008

2417 Valentina Bosetti, Carlo Carraro, Alessandra Sgobbi and Massimo Tavoni, Modelling Economic Impacts of Alternative International Climate Policy Architectures. A Quantitative and Comparative Assessment of Architectures for Agreement, October 2008

2418 Paul De Grauwe, Animal Spirits and Monetary Policy, October 2008

2419 Guglielmo Maria Caporale, Christophe Rault, Robert Sova and Anamaria Sova, On the Bilateral Trade Effects of Free Trade Agreements between the EU-15 and the CEEC-4 Countries, October 2008

2420 Yin-Wong Cheung and Daniel Friedman, Speculative Attacks: A Laboratory Study in Continuous Time, October 2008

2421 Kamila Fialová and Ondřej Schneider, Labour Market Institutions and their Effect on Labour Market Performance in the New EU Member Countries, October 2008

2422 Alexander Ludwig and Michael Reiter, Sharing Demographic Risk - Who is Afraid of the Baby Bust?, October 2008 
2423 Doina Maria Radulescu and Michael Stimmelmayr, The Welfare Loss from Differential Taxation of Sectors in Germany, October 2008

2424 Nikolaus Wolf, Was Germany ever United? Evidence from Intra- and International Trade 1885 - 1933, October 2008

2425 Bruno S. Frey, David A. Savage and Benno Torgler, Noblesse Oblige? Determinants of Survival in a Life and Death Situation, October 2008

2426 Giovanni Facchini, Peri Silva and Gerald Willmann, The Customs Union Issue: Why do we Observe so few of them?, October 2008

2427 Wido Geis, Silke Uebelmesser and Martin Werding, Why go to France or Germany, if you could as well go to the UK or the US? Selective Features of Immigration to four major OECD Countries, October 2008

2428 Geeta Kingdon and Francis Teal, Teacher Unions, Teacher Pay and Student Performance in India: A Pupil Fixed Effects Approach, October 2008

2429 Andreas Haufler and Marco Runkel, Firms' Financial Choices and Thin Capitalization Rules under Corporate Tax Competition, October 2008

2430 Matz Dahlberg, Heléne Lundqvist and Eva Mörk, Intergovernmental Grants and Bureaucratic Power, October 2008

2431 Alfons J. Weichenrieder and Tina Klautke, Taxes and the Efficiency Costs of Capital Distortions, October 2008

2432 Andreas Knabe and Ronnie Schöb, Minimum Wage Incidence: The Case for Germany, October 2008

2433 Kurt R. Brekke and Odd Rune Straume, Pharmaceutical Patents: Incentives for R\&D or Marketing?, October 2008

2434 Scott Alan Carson, Geography, Insolation, and Institutional Change in $19^{\text {th }}$ Century African-American and White Stature in Southern States, October 2008

2435 Emilia Del Bono and Daniela Vuri, Job Mobility and the Gender Wage Gap in Italy, October 2008

2436 Marco Angrisani, Antonio Guarino, Steffen Huck and Nathan Larson, No-Trade in the Laboratory, October 2008

2437 Josse Delfgaauw and Robert Dur, Managerial Talent, Motivation, and Self-Selection into Public Management, October 2008

2438 Christian Bauer and Wolfgang Buchholz, How Changing Prudence and Risk Aversion Affect Optimal Saving, October 2008 
2439 Erich Battistin, Clara Graziano and Bruno Parigi, Connections and Performance in Bankers' Turnover: Better Wed over the Mixen than over the Moor, October 2008

2440 Erkki Koskela and Panu Poutvaara, Flexible Outsourcing and the Impacts of Labour Taxation in European Welfare States, October 2008

2441 Marcelo Resende, Concentration and Market Size: Lower Bound Estimates for the Brazilian Industry, October 2008

2442 Giandomenico Piluso and Roberto Ricciuti, Fiscal Policy and the Banking System in Italy. Have Taxes, Public Spending and Banks been Procyclical in the Long-Run? October 2008

2443 Bruno S. Frey and Katja Rost, Do Rankings Reflect Research Quality?, October 2008

2444 Guglielmo Maria Caporale, Antoaneta Serguieva and Hao Wu, Financial Contagion: Evolutionary Optimisation of a Multinational Agent-Based Model, October 2008

2445 Valentina Bosetti, Carlo Carraro and Massimo Tavoni, Delayed Participation of Developing Countries to Climate Agreements: Should Action in the EU and US be Postponed?, October 2008

2446 Alexander Kovalenkov and Xavier Vives, Competitive Rational Expectations Equilibria without Apology, November 2008

2447 Thiess Buettner and Fédéric Holm-Hadulla, Cities in Fiscal Equalization, November 2008

2448 Harry H. Kelejian and Ingmar R. Prucha, Specification and Estimation of Spatial Autoregressive Models with Autoregressive and Heteroskedastic Disturbances, November 2008

2449 Jan Bouckaert, Hans Degryse and Thomas Provoost, Enhancing Market Power by Reducing Switching Costs, November 2008

2450 Frank Heinemann, Escaping from a Combination of Liquidity Trap and Credit Crunch, November 2008

2451 Dan Anderberg, Optimal Policy and the Risk Properties of Human Capital Reconsidered, November 2008

2452 Christian Keuschnigg and Evelyn Ribi, Outsourcing, Unemployment and Welfare Policy, November 2008

2453 Bernd Theilen, Market Competition and Lower Tier Incentives, November 2008

2454 Ondřej Schneider, Voting in the European Union - Central Europe's Lost Voice, November 2008 
2455 Oliver Lorz and Gerald Willmann, Enlargement versus Deepening: The Trade-off Facing Economic Unions, November 2008

2456 Alfons J. Weichenrieder and Helen Windischbauer, Thin-Capitalization Rules and Company Responses, Experience from German Legislation, November 2008

2457 Andreas Knabe and Steffen Rätzel, Scarring or Scaring? The Psychological Impact of Past Unemployment and Future Unemployment Risk, November 2008

2458 John Whalley and Sean Walsh, Bringing the Copenhagen Global Climate Change Negotiations to Conclusion, November 2008

2459 Daniel Mejía, The War on Illegal Drugs in Producer and Consumer Countries: A Simple Analytical Framework, November 2008

2460 Carola Frydman, Learning from the Past: Trends in Executive Compensation over the Twentieth Century, November 2008

2461 Wolfgang Ochel, The Political Economy of Two-tier Reforms of Employment Protection in Europe, November 2008

2462 Peter Egger and Doina Maria Radulescu, The Influence of Labor Taxes on the Migration of Skilled Workers, November 2008

2463 Oliver Falck, Stephan Heblich and Stefan Kipar, The Extension of Clusters: Differencein-Differences Evidence from the Bavarian State-Wide Cluster Policy, November 2008

2464 Lei Yang and Keith E. Maskus, Intellectual Property Rights, Technology Transfer and Exports in Developing Countries, November 2008

2465 Claudia M. Buch, The Great Risk Shift? Income Volatility in an International Perspective, November 2008

2466 Walter H. Fisher and Ben J. Heijdra, Growth and the Ageing Joneses, November 2008

2467 Louis Eeckhoudt, Harris Schlesinger and Ilia Tsetlin, Apportioning of Risks via Stochastic Dominance, November 2008

2468 Elin Halvorsen and Thor O. Thoresen, Parents' Desire to Make Equal Inter Vivos Transfers, November 2008 